\title{
ICTs and Their Applications in Education
}

\author{
Guadalupe Martínez, Ángel Luis Pérez, $\mathrm{M}^{\mathrm{a}}$ Isabel Suero and Pedro J. Pardo \\ University of Extremadura \\ Spain
}

\section{Introduction}

The continuous changes that are occurring in society today because of advances in science and technology require new models and social patterns to be developed and implemented in many fields, a prominent one of which is that of education (Barberá et al., 2008; Coll, 2004; Garrison \& Anderson, 2003). We are living in what is often called the Information Age, and which has been evolving into the so-called Knowledge Society. According to Crook (Crook, 1996), education needs to be re-thought in depth to adapt to this new kind of society characterized by knowledge, information, and communication. Indeed, these innovations are already bringing about the birth of a new type of education supported by the widespread diffusion of Information and Communication Technologies (ICTs).

There has been growing research interest in studying the impact of ICTs on educational processes, in parallel with the growing adoption of these technologies at all levels of teaching and learning (Coll et al., 2008). Some authors (Bajarlía \& Spiegel, 1997) have noted that students maintain a constant relationship with the technologies that they have grown up with, which allows one to observe the progress of their learning using interactive media, monitoring how, and how much, they learn. In this sense, ICTs in education are seen from two perspectives: learning with them and learning from them (Finol de Govea, 2007). Some authors (Järvelä \& Häkkinen, 2002; Kennewell \& Beauchamps, 2003; Squires \& McDougall, 1994; Tondeur et al., 2007; Twining, 2002) have studied empirically the way in which teachers and students use ICTs in the actual development of the practical work they do in class. This influence of ICTs on education has been investigated by many other authors (Balanskat et al., 2007; Cabero et al., 2003; Cattagni \& Farris, 2001; Cebrián, et al., 2007), and indeed is the subject of the work to be described in this chapter which deals with the particular processes of teaching and learning in either purely virtual environments or in presential environments that include new educational materials using ICTs. Some research (Chi et al., 2001; Lehtinen et al., 1999) has focused on such aspects as the teacher's role, the learning undertaken by students in these new environments, or how knowledge is actually constructed using these new virtual tools (Arvaja et al., 2007). Other authors (Beller, 1998) have discussed the importance of integrating ICTs into teaching and learning to make the process more effective. This has led to the emergence of e-learning as an important innovative platform for teaching.

Some research (Yazón et al., 2002) indicates that the use of technology promotes a different way of thinking about teaching and learning provided that it is genuinely student-centred learning, and not treated just as a simple reprise of the "old model" (directed by the teacher) 
in a new technological environment (Harris, 1999). Others (Coll et al., 2007) note that some authors (Blease \& Cohen, 1990; Squires \& McDougall, 1994; Twining, 2002) propose directing effort to studying how ICTs are transforming teaching practices.

In recent years, one of the major lines of research has been on how ICTs can be integrated into the teaching and learning process. There have been various studies considering a variety of forms of integration. For some authors (M. Grabe \& C. Grabe, 1996), ICT integration should be undertaken as an extension of the traditional teaching process, not as a complete replacement. For others authors (Merrill et al., 1996), for the result to be an enhancement of learning, integration will have to imply a combination of ICTs with traditional teaching procedures, a combination known as "blended learning" or b-learning, designed to move the student to a new level of understanding. According to Gros (Gros, 2000), one form of successfully integrating technology into the curricula is to regularly use ICTs for information, experimenting, simulating, or communicating. This author therefore goes beyond the mere instrumental use of the tool to focus on the content that the students will be taught (Gros, 2000). Other authors have shown the importance of ICTs after assessing the educational possibilities they represent in an objectives-based framework (Reparaz et al., 2000), and accept the need for a change in the roles of both teacher and student (Adell, 1997; Bartolomé, 1996; Cebrián, 1997; Poves, 1997; Reparaz et al., 2000; Roca, 2001; Sánchez, 2000, 2001). While some point out that it is the curriculum which guides the use of ICTs, and not the other way round (Dockstader, 1999), others argue that they should be introduced so as to provoke educational innovation (Dede, 1998; Gros, 2000). For example, both teachers and students are found to be eager to appropriate ICTs into their teaching and learning activities (Area, 2005; Cuban, 2001; Zhao et al., 2002; Zhao \& Frank, 2003), facilitating the implementation of innovations.

The use of ICTs allows one to count on a new way to organize, represent, or simulate reality, being effective tools to help achieve a high degree of application of the knowledge acquired in class. Since they allow students to work in collaboration, to use virtual laboratories, display laboratory experiments over the Internet or on their mobiles, they are an excellent resource for learning both concepts and procedures. Indeed, these features make ICTs an especially useful tool for science teaching in general, and physics in particular. For these reasons, the integration of ICTs into science education is emerging as an essential element of the so-called knowledge society. There also stands out the optimal conditions such integration would present for constructivist learning. In recent years, many researchers have explored the role technology can play in constructivist learning, demonstrating that computers provide an appropriate environment for students to express themselves and show that they have acquired new knowledge. From this perspective, technological factors can serve as teaching tools to foster the construction of knowledge (Vélez, 2002).

For Coll (Coll et al., 2007), ICTs reveal their greatest mediating capacity as "psychological instruments" when they are actually used as "cognitive instruments" (Lajoie et al., 1998; Lajoie, 2000; Lajoie \& Azevedo, 2006; Salomón et al., 1991) or "tools of the mind" (Jonassen, 1996, 2000), i.e., when they are used so that the student has to establish meaningful connections with the content being studied. However, ICTs are not cognitive tools in themselves. Rather, they are technological tools which, due to the properties of the environments that they make it possible to create, can be used to organize and structure the processes involved in teaching and learning.

In this vein, we believe that ICTs are currently stimulating the emergence of new approaches to the organization of education in the European Higher Education Area 
(EHEA) from the standpoints of both research and teaching. For example, one of the most significant current initiatives being developed in almost all areas of study is that of virtual learning platforms or e-learning. To properly implement the teaching process in these new learning environments, one must have appropriate educational materials available that can serve as the fundamental support for the new methods of teaching and learning. These materials themselves can be developed and shared through ICTs.

The work to be presented is centred on the subject of Optoelectronics, a subject that we teach in the second cycle of the degree in Electronics Engineering at the School of Industrial Engineering of the University of Extremadura (Spain). The overall objective was to create educational tools for university education in optoelectronics designed for application on elearning platforms. Within this overall objective, our aim was to design, prepare, validate, and apply teaching materials from a conceptual, experimental, and didactic perspective.

Figure 1 is a concept map that summarizes the core of this work: the use of ICTs to design and create teaching tools that can be implemented together in the form of a virtual laboratory. With the design and development of such virtual laboratories, students have a system available with which to carry out a study analogous to what could be done with a real system. This has allowed university laboratories to go beyond the physical limits imposed by the traditional means available to them in teaching certain subjects (Aktan et al., 1996; Calvo et al., 2009; Candelas et al., 2004; Domínguez et al., 2005; Dormido, 2004; Guzmán et al., 2005; Laschi \& Riccioni, 2008; Riccioni 2010; Salzmann et al., 2000; Yanitelli, 2011).

Specifically, as shown in Figure 1, in the present work:

- We have designed, developed, and validated techniques for structuring information, using for this purpose Concept Maps and the CmapTools software tool to construct, store, and share them. We include learning materials to facilitate the students' learning of the technique of constructing these maps.

- We have studied the latest developments in the field of information communication, such as optical communications, fibre optics, and other optoelectronic devices.

- We have designed, developed, and validated content that can be shared through ICTs. We include learning materials to facilitate the students' construction of new content of this type. This content is as diverse as concept maps, computer simulations (which have evolved from analogue to digital and hyper-realistic), videos of laboratory practicals, multimedia video-tutorials, Web pages, explanations using presentation software, etc.

The originality of our work is that it combines the "hard" science part (such as the study of optical fibres or of the software with which to perform hyper-realistic simulations) with techniques of structuring and organizing information (a part which is more typical of other disciplines closer to the social sciences). The methodology employed in this work is based on the Theory of Meaningful Learning (Ausubel, 1968, 2002) and the Elaboration Theory of Instruction (Reigeluth, 1983) with the modifications put forward by our research group (Pérez et al., 1999, 2004). These theories have guided us in how we design, elaborate, and put into practice a learning process characterized by the use of the new technologies. In section 2 we make our proposal on the theoretical framework used to develop new educational materials that employ ICTs. Subsequently, in Sections 3, 4 and 5 we use this proposal on the development of simulations, instructional videos and concept maps. Finally, in the concluding section we show the results of the application in the classroom of these new educational materials developed, and provide a summary of future work. 


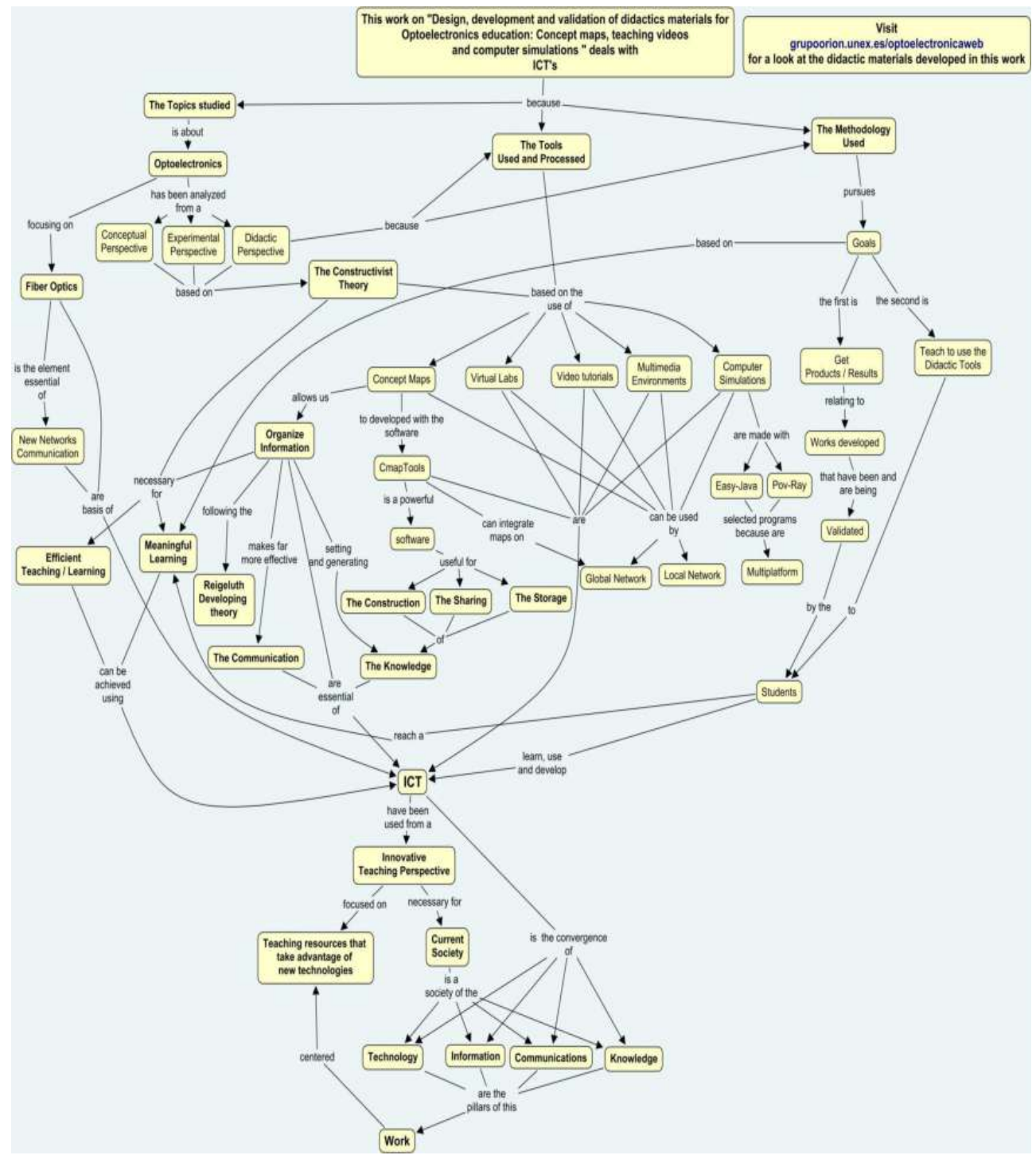

Fig. 1. Concept map showing the focus of our research.

\section{ICTs: Use in the elaboration of teaching materials for science education}

The teaching materials our research group has elaborated are developed and implemented through ICTs. Theoretically, they are founded on constructivist theories of learning. Each of the educational activities carried out with these materials has specific cognitive demands. Therefore, the learning environment used, such as virtual learning platforms, must provide 
the students with the appropriate educational tools for these cognitive demands. The cognitive tools that are included in these e-learning or b-learning environments are ICT instruments, aimed at facilitating our students' acquisition of knowledge. Examples are materials used to display, represent, and organize content, fostering the effective transfer of knowledge between teacher and student and among the students themselves.

We have developed various types of educational tools. Some are used to better represent the hierarchy of the content, or the problem or experiment being dealt with in class (e.g., concept maps). A second group help to change the student's mindset by presenting a given physical phenomenon in different situations (for example, as traditional computer simulations and as hyper-realistic simulations). Others (e.g., virtual laboratories, explanatory instructional videos, video-tutorials, etc.) can help bring together in one place the information needed to solve a problem, do some given laboratory practical, or study a particular subject. According to Jonassen (as cited in Reigeluth, 1983), educational tools should be appropriate to the student's learning process, and have to be carefully selected to support the type of procedure needed for each cognitive task.

In teaching science (and physics in particular) as also in other disciplines, ICTs are commonly used to search for and communicate information, or to prepare teaching materials. Beyond this common usage, however, other resources offered by ICTs have proved helpful for science education. For example, Sims (Sims, 2000) notes that interactivity in e-learning is already accepted as implying a certain level of effectiveness and a guarantee of learning. Indeed, this assertion has been basic for us at the time of designing and implementing our computer simulations.

The use of ICTs in a cognitive-constructivist approach to education is the key to a more active, contextualized, authentic, and constructive learning process (Finol de Govea, 2007). Their use in simulating reality can facilitate meaningful learning by bringing the student and the real world closer together.

We consider that it is necessary in the teaching process to transform information into knowledge, e.g., through concept maps. This process requires the content to be selected, structured, and organized, which can be accomplished through virtual learning environments and the use of Internet (Linn, 2002).

Computers today play an important role in acquiring and applying scientific knowledge, thus facilitating science learning. Specifically, to speak of ICTs in teaching or learning demands that particular emphasis be placed on the means and resources needed for the activities, content, and educational objectives of any given topic. It is essential to consider carefully the type of materials that we shall use in our teaching practice to ensure its suitability for the transmission of the information contained in the topic, and its capacity to stimulate the students' mental activity and to connect to their cognitive characteristics.

Thus, in an essentially practical science subject such as optoelectronics, we consider that experimental work is an integral part of its character, so that one needs to implement educational materials that can meet these procedural objectives. For that, we have developed virtual laboratories and instructional videos of laboratory practicals which have provided students and teachers with new teaching models with which they can carry out laboratory experiments in virtual environments. From the perspective of teaching a scientific discipline, we therefore consider it necessary to design and elaborate learning situations in which laboratory practicals receive a specific treatment, and in which ICTs can make a significant contribution to the education of students in that area. 
The goal pursued in the present research was to incorporate some of these learning tools into our teaching programs from a pedagogical perspective, and to validate their effectiveness after using them with our students.

Specifically, we propose a teaching model which is in accordance with the theories of cognitive learning. In particular, the teaching methodology of these theories has guided how we design, elaborate, and put into practice a learning process characterized by the use of the new technologies. Each of the teaching material proposals developed in this research will be described individually in the different sections of this chapter.

\section{Computer simulations: ICT tools to facilitate meaningful learning}

ICTs provide teaching tools that are found to be very effective in the learning process based on virtual platforms. In e-learning, virtual laboratories are particularly useful because of the aid they can provide students when they are carrying out practical activities. According to the UNESCO, a virtual laboratory is defined as a workspace for remote collaboration and experimentation aimed at doing research or similar activities, and at reporting and disseminating the results by means of ICTs (UNESCO, 2000). Some authors (Psillos \& Niedderer, 2002) indicate that, by coordinating experimentation activities with simulation, the latter can serve as a cognitive bridge between theory and practice. For others (Marqués, 2000), virtual laboratories are virtual learning environments that take advantage of the capabilities offered by ICTs to create a teaching environment that is free from the constraints of time and space in presential education, capable of ensuring ongoing virtual communication between students and teachers.

Virtual laboratories are based on the simulation of real phenomena. They provide learning environments in which students can construct their own meaningful knowledge that is transferable to other phenomena having the same underlying physical principle. In this sense, simulation is a powerful computer tool of widespread use in all sectors of society, and its definition will naturally depend on the field in which it is applied. In our case, we are interested in the field of education, in which such simulation can be defined as a computer program that reproduces a real phenomenon, but in a simplified form designed to provide specific learning situations (Alessi \& Trollip, 1991). Computer simulations that allow interaction on the part of the student can constitute effective virtual laboratories in their process of learning. This is principally because the students can study the actual system and investigate its behaviour in response to changes in some of its parameters by making measurements, etc. In this way, students will not be using the simulation mechanically, but will be immersed in a process oriented to producing meaningful learning through the use of virtual laboratories.

In physics teaching specifically, many authors have highlighted the nature of computer simulations as cognitive tools (Bryan \& Slough, 2009; Chang et al., 2008; Finkelstein et al., 2005; Landau, 2006; Naps et al., 2003; Ronen \& Eliahu, 2000; Trumper, 2003; Zacharia \& Anderson, 2003), since their use is highly beneficial for conceptual development and change, and for understanding many physical phenomena in various areas of study, for example, in mechanics (Gorsky \& Finegold, 1992; Tao \& Gunstone, 1999), optics (Eylon et al., 1996; Goldberg, 1997; Tao, 2004), or across the curriculum in general (Zacharia \& Anderson, 2003). However, the integration of simulations into the curriculum requires their effectiveness to be evaluated. Specifically, over the course of the last two decades the positive impact of computer simulations has been documented in different stages of the teaching and learning 
process. Some authors (Snir et al., 1995) affirm that, with computer simulations, the learning process is far more efficient and applicable to problems or situations of the real world. Other studies have shown their benefits for cognitive development, skills, conceptual understanding, etc. (Goldberg \& Bendall, 1995; Goodyear et al., 1991; Gorsky \& Finegold, 1992; Hewson, 1985; Kaput, 1995; Shin et al., 2003; Tao \& Gunstone, 1999; Zacharia \& Anderson, 2003). Many of these workers have shown that groups of students who have worked with computer simulations learn more successfully (Baily \& Finkelstein, 2009; Finkelstein et al., 2005; Zacharia \& Anderson, 2003), although other authors argue that the benefits of learning through simulations are ambiguous (Steinberg, 2000), or that the practices carried out in virtual environments are useful as an educational complement, but cannot replace the real laboratory (Aleksandrov \& Nancheva, 2007).

The potential educational value of computer simulations in virtual laboratories lies in their ability to reproduce phenomena with varying degrees of complexity, so that they can be adapted to the students' cognitive level, or to attaining some given educational objective. The ability to interact with the software allows students to modify the conditions of the processes involved, and to analyze the changes they observe. This makes simulation an extremely useful tool in experimental work. Indeed, its possibilities of application seem limitless.

Our research group has a long experience in the development and use of computer simulations, from analogue simulations of more than 25 years ago before the boom in personal computers (Calvo \& Pérez, 1983; Pérez et al., 1979a, 1979b; Pérez \& Calvo, 1984), to the digital simulations we are working on now. Despite the repeatedly proven teaching effectiveness of simulations, one of the challenges we constantly have to face in developing a simulation is how to adequately reproduce the phenomenon in question. For example, experiments in virtual spaces offer a new approach to presenting the abstract concepts of a real phenomenon. We have often observed that, in the more applied areas of science, some students have serious difficulties in reliably identifying what they observe in the simulated model with reality. In the more theoretical areas, however, it suffices to present purely abstract constructions such as those provided by traditional computer simulations, while in applied areas it is important to include not only the properties characteristic of the basic phenomenon, but also a certain degree of reality in the experiment.

This conflict between the abstract or idealized and the concrete or real has been analyzed by some authors. Goldstone \& Son (2005) discusses the trade-off between the advantages of concrete simulations and the benefits of simulations with more idealized models. For Difanzo et al. (1998), a high level of detail by means of realistic representations of objects within the simulation can benefit students in their study of a particular phenomenon by increasing the similarity between the simulation and the real world. Indeed, most research on virtual reality has had the specific purpose of the realistic imitation of real-world phenomena (Grady, 1998). Other authors have argued, however, that relatively simplified and idealized representations are useful for distilling a situation to its essence (Goldstone \& Sakamoto, 2003).

Thus, some authors stress the importance of the simplification of reality involved in simulations, of omitting or changing details, since they find the advantage to lie in focusing the students' attention on the development of certain skills (Alessi \& Trollit, 1991; M. Grabe \& C. Grabe, 1996). But others, taking a constructivist perspective, value the students' opportunity to perform complex tasks in scenarios that simulate real life (García \& Gil, 2006; Lajoie \& Azevedo, 2006). In this latter case, the simulations reflect the complexity of the real 
phenomena, allowing the students to develop cognitive skills and re-structure their mental models when they compare the behaviour of the models with reality.

Schematic simulation, for example, is a dynamic, simplified representation of the behaviour of a system. It allows students to manipulate data and examine the consequences, avoiding the confusion and insecurity that would be involved in a complex environment. It can enrich the constructivist approach to learning by enabling students to anchor their cognitive understanding in what they observed through their actions in a given situation (Harper et al., 2000).

While some authors have argued for the benefits of idealization as against the concrete for the acquisition of underlying abstract physical principles, the main objective of our simulations is to fill the gap the student has in realistic situations when faced with observing a real phenomenon after having studied it in a schematic simulation. In this regard, we must distinguish between simulations which "simulate the result", and those which "simulate the experience". Thus, schematic simulations in Java are useful to simulate results. For example, if we remove all the details, and focus schematically on the underlying foundation of the physical phenomenon, one can effectively transfer abstract phenomenon to other scientific fields (Goldstone \& Son, 2005). In this regard, we consider that it would be very effective for our students' learning if they could also "simulate the performance of the experience", i.e., if we added to the simulation of the system a realistic visual output of the phenomenon being simulated. In the particular field of our area of education, Optics, the objective of our simulations is to "simulate the experience" - to show students what the abstract phenomenon simulated schematically in Java looks like in reality, creating a hyper-realistic simulation of the phenomenon in its entirety, i.e., the simulated experience.

In our research, we have focused on the development of a virtual environment with computer simulations that have a greater degree of reality than traditional ones. To implement these simulations, we used computer tools designed specifically for scientific environments, and which are freely available and aimed at users who are not programming specialists. Among these tools, we would highlight EJS and POV-Ray, both of free distribution. A common feature of these two environments is that they allow the user to concentrate efforts on the model of the system being studied, and greatly facilitate the entire process of creating the graphical interface and its connection with the model. This is a great advantage in preparing simulations, since one can focus on modeling the phenomenon or system without getting lost in programming the code. With our students, we use EJS which produces Java applets that are easily distributed, and POV-Ray which allows us to complement the Java applets by endowing them with hyper-realism. The result is a virtual learning environment that requires the active involvement of the student, and thus ensures deeper learning.

To summarize the above, interactive simulations facilitate deeper learning of concepts, since it is the students themselves who observe the physical phenomenon and can interact with the model to create mental structures from which to construct their own conceptual models of the phenomenon.

The computer simulations we have implemented form part of a virtual teaching approach using e-learning platforms. Specifically, we use the AVUEX virtual campus of our university with the Moodle platform. These platforms strengthen group work in the form of collaboration between teacher and students and among the students themselves, fostering a constructivist learning environment. Examples of these simulations can be found on our group's website: http://grupoorion.unex.es. 


\section{Instructional videos: ICT tools to facilitate meaningful learning}

The introduction of new virtual platforms with innovative teaching resources into the teaching of experimental sciences is one of the most interesting approaches to teaching today. There are already a great many resources in the fields of engineering education which are related to virtual or remote laboratories (Aktan et al., 1996; Calvo et al., 2009; Candelas et al., 2004; Domínguez et al., 2005; Dormido, 2004; Guzmán et al., 2005; Laschi \& Riccioni, 2008; Riccioni 2010; Salzmann et al., 2000; Yanitelli, 2011).

One concern among teachers of all educational levels, including the university level, is to improve education from both a conceptual and a practical point of view. In this line, one of the objectives of the present work has been to organize and elaborate teaching materials designed for both theoretical classes and laboratory practicals, which will motivate the students and promote meaningful learning.

Today, there is increased use of ICTs in teaching scientific and technical subjects, due to the large amount of educational resources that can be elaborated from them. Among these teaching resources, we have noted above the great interest in the use of virtual laboratories, especially in scientific fields such as engineering. Laboratory practicals are a vital educational resource in teaching experimental and technical disciplines, allowing the student to check the degree of assimilation of the theoretical content. However, practical classes sometimes involve a degree of difficulty for students in terms of understanding the experiment. These difficulties may refer either to the physical foundations of the specific laboratory practical involved, or to the functioning of the instruments used.

This work proposed the introduction of ICTs to improve not only the theoretical classes with concept maps or computer simulations, but also laboratory practicals through the design of audiovisual teaching materials dealing with the physical fundamentals and the development of the experiments. Particularly worthy of note among the various means of supporting practical teaching in the laboratory is the use of instructional videos. One can present in them the most interesting and significant aspects of the laboratory practice, adding animations and a multitude of multimedia resources to them to facilitate the teacher's work.

Specifically, we have developed audiovisual materials to support practical work on the subject of Optoelectronics. The virtual laboratories created from the incorporation of these instructional videos have provided a tool that fosters constructivist learning, and hence encourages conceptual change, by means of an organized sequence of proposals for the students to do. These activities stimulate the students to reflect on the information and content they receive.

We believe that the introduction in various formats of audiovisual materials to complement the course's traditional laboratory script can help the student get more out of the laboratory classes, since these materials can provide both theoretical and practical details of the experiments. They can also be a complement to simulation software, as with them the student can see the experimental techniques that are used to study the simulated phenomenon.

Moreover, instructional videos constitute a virtual guide to the experiments that the student will carry out. This is an advantage when there is little laboratory equipment available but various students have to work simultaneously in the laboratory, or when the student is working non-presentially. 
Therefore, approaching laboratory practicals sequentially in an instructional video can optimize both the available material resources since not all the groups of students have to use the same material simultaneously, and the available time since it allows the student to carry out more complex experiments or a greater number of them.

In our research, we designed and implemented a teaching innovation project whose aim was either to facilitate the students' preparation prior to their actually doing the laboratory practicals, or for them to carry out those practicals on virtual e-learning and b-learning platforms using the facilities provided by ICTs. In particular, audiovisual material was developed in several formats, and implemented on a Website, covering the content necessary for the study and practical preparation of the subject of Optoelectronics, a subject that we teach in the second cycle of the degree in Electronic Engineering at the School of Industrial Engineering of our University. All of the instructional videos produced have a common structure. They begin with the title of the practical, a brief introduction to put it into the context of the subject, and a description of the basic theoretical concepts related to the experiment they are going to see. The objective proposed by the experiment is indicated, the material used is shown, and then particular emphasis is laid on the steps to follow in doing the experiment. Finally, it is explained how the data should be analyzed and presented.

The methodological approach to the virtual practicals follows the guidelines for the design of virtual learning material proposed by Onrubia (Onrubia, 2005). Specifically, apart from exploiting the technical possibilities offered by ICTs, the materials should also be consistent with two features:

- "Logical meaningfulness": From a constructivist viewpoint, the virtual educational material developed must have a clear organization and structuring of its content. Logical meaningfulness needs to be ensured in the design phase, i.e., with the logical structure of the content. This aspect is taken into account in the organization of the various elements, activities, and sequences that make up the materials being developed.

- "Psychological meaningfulness": The materials should enable the learners to have cognitive elements available that they can relate to the content being studied. Psychological meaningfulness emerges during the students' actual learning process. Therefore, this phase of design will deal with how the material is integrated into our overall teaching methodology, in order to ensure that the students will have developed the cognitive resources needed to assimilate the new content and establish meaningful relationships.

One of the support platforms we use for the instructional videos is the Moodle virtual platform. As indicated by various authors (Coll, 2004; Donnelly, 2005; Mauri et al., 2005; Mauri, 2006; Onrubia, 2005), this can amplify the educational benefits the students obtain from the process, and provides support to them when they are working independently either individually or in groups.

This virtual laboratory in no way means that we are contemplating the disappearance of the real laboratory. Instead our intention is the integration of the two laboratories in our teaching practice. Indeed, it forms part of a teaching methodology which foresees increasing use of a wide range of learning tools that can facilitate successful adaptation to the European Higher Education Area.

Figure 2 shows several screenshots from some instructional videos about optical communications. 


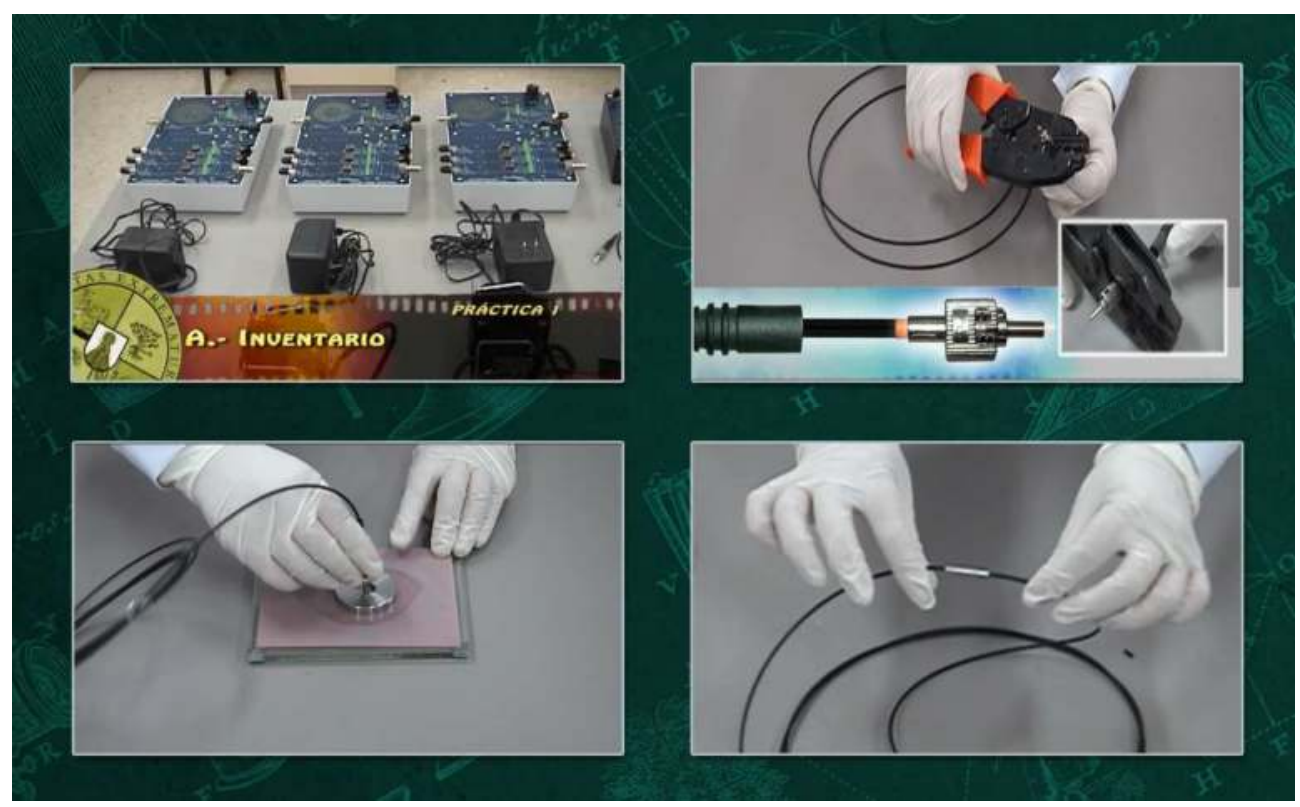

Fig. 2. Some screenshots from the instructional video "Virtual Laboratory on Optical Communications".

The materials developed are available at: http://grupoorion.unex.es.

\section{Concept maps: ICT tools to facilitate meaningful learning}

In keeping with the purpose of creating learning environments grounded in constructivist theories and meaningful learning (Ausubel, 1968), we apply concept maps (Novak \& Gowin, 1984) as a strategy for cognitive organization, and as a visual resource with which to represent a set of conceptual meanings included in a proposition structure. The idea is to display the meaningful relationships between the concepts of the specific content to be taught and the students' knowledge of the subject.

The concept map constitutes an ideal teaching material with which to associate, interrelate, structure, discriminate, describe, and exemplify the content of a subject. To these characteristics, one must add that in recent years the technique has become very popular due to its natural integration with ICTs. In sum, concept maps are today very useful educational tools to help achieve meaningful learning (Ausubel, 1968; Novak \& Gowin, 1984; Moreira, 2010).

For scientific subjects in particular, authors such as Novak \& Musonda (1991) have pointed out that, in physics teaching, the subject matter may be regarded as "conceptually opaque". I.e., students find it hard to visualize the structure of the concepts involved, and the relationships between them. It is therefore important if that matter is to be learnt meaningfully for it to be presented in a "conceptually transparent" form, i.e., it is necessary to present the topics to students with a clearly related conceptual hierarchy.

The concept map is therefore a tool that is consistent with Novak's educational theory, and part of its usefulness is in detecting and facilitating meaningful learning (Pérez et al., 2004, 
2006, 2008, 2010a). The concept map shows schematically an image of a person's knowledge about some particular topic, so that it can also reflect the extent to which that knowledge is the product of a process of meaningful learning. The map shows a series of concepts, organized hierarchically, together with the relationships that are established between them, thus explicitly showing the meanings with which each concept has been endowed.

Concept maps have been used at different educational levels because they allow students to better assimilate the concepts they are learning by a development of new propositions that they integrate into their existing cognitive structure, the result being meaningful learning (Jonassen, 2000; Novak \& Gowin, 1984; Okebukola \& Jegede, 1988; Roth \& Roychoudhury, 1994). In the Theory of Meaningful Learning, the learning process consists of an interaction between the knowledge already existing in the student's cognitive structure and the new knowledge being assimilated. Building on the foundations of this theory, if used to their full potential, concept maps are particularly effective in encouraging meaningful learning, allowing students to construct their knowledge by organizing conceptual content into a hierarchical structure (Novak \& Gowin, 1984; Novak \& Musonda, 1991; Cifuentes \& Hsieh, 2003; Kwon \& Cifuentes, 2009; Haugwitz et al., 2010; Pérez et al., 2004, 2006, 2010a).

How the concepts are organized in a concept map (whether more linearly or more differentiated) can indicate the extent to which the creator of the map has learnt more by rote or more in a meaningful form. It is precisely this aspect that makes concept maps such powerful teaching tools. In particular, the meaningfulness of the student's learning will be easily perceptible when its content is organized into an interrelated structure. The elaboration of concept maps allows new information to be organized and related to the already existing cognitive structure, and clearly highlights the establishment of any erroneous relationships or the absence of any relevant concepts. As noted by Novak \& Gowin (1984), students will perceive meanings to a greater or lesser extent depending on the new propositional relationships that they have noted and understood. With their use, the learner develops important analytical skills: the selection, organization, and elaboration of knowledge. The tasks involved in their construction and the interpretation of the cognitive structures they contain develop the students' intellectual skills.

Today, thanks to advances in the new technologies, there are many software tools available for the construction of concept maps. Examples are CmapTools, Inspiration, and CMT, inter alia. Various studies have shown the advantages in using such computer programs to facilitate constructing these maps (Alpert \& Grueneberg, 2001; Anderson-Inman \& Ditson, 1999; Cline et al., 2010; Haugwitz et al., 2010; Kwon \& Cifuentes, 2009; Reader \& Hammond, 1994).

Our research group uses concept mapping as a working tool in physics teaching (Pérez et al., 2000, 2004, 2006, 2010a, 2010b). For their construction, we chose CmapTools of the IHMC (Institute for Human and Machine Cognition, University of West Florida, Pensacola, FL) (Cañas et al., 2000; Novak \& Cañas, 2006). This is a toolkit that facilitates the creation of concept maps on a computer, using applications written in Java. It provides the ability to construct, navigate through, share, and critically negotiate models of knowledge represented as concept maps. It also allows their use in collaborative networks over the Internet, so as to facilitate group work. Thus, CmapTools users constitute a community which shares knowledge and technologies. Projects can be easily shared worldwide thanks to a public server network, accessible from any browser or through the free CmapTools software.

In our research, we have developed concept maps that are models of knowledge for teaching topics of physics, which were subsequently used by our students in validating their educational effectiveness. 
The concept maps that we and our students have created (several thousand) are lodged on the Cmap site: "Universidad de Extremadura (España)", and in this way are integrated into the global network of concept maps hosted on Cmap sites, and that is distributed throughout the world. The ideal way to see them is to install the CmapTools software application on the computer, and visit the aforementioned Cmap site. Nevertheless, they can also be seen (with some limitations) at the Web address: http:/ /grupoorion.unex.es:8001.

\section{Conclusion}

In general, we can say that the educational materials developed in this work have improved the quality of the e-learning of the subject of Optoelectronics, both of the conceptual content through the use of concept maps, and of the procedural content through instructional videos, computer simulations, and virtual laboratories.

The concept maps developed have been validated by comparison with traditional teaching following an experimental design with a control group and an experimental group (Martínez et al., 2010a; Pérez et al., 2010a, 2010b; Suero et al., 2010). A test of knowledge was applied to determine the learning actually achieved by the students of the two groups. The results showed that the concept maps that were constructed had been an effective teaching tool in physics teaching in general, since they helped the students to learn meaningfully the concepts of the topic under study, constituting a useful cognitive strategy for acquiring information in a structured form, and for discovering the meaning of the concepts that were being learnt.

The instructional videos and virtual laboratories mounted on e-learning platforms have been validated through an experimental design with two control groups of students and one experimental group (Martínez et al., 2010b, 2011). The results of different post-tests of knowledge showed these teaching materials to be effective teaching tools in enhancing students' learning. For Optoelectronics in particular, the application of our teaching methodology contributed a clear improvement over the conventional system of teaching the topic. The purpose of using this type of material is their application to e-learning platforms as complements to traditional teaching, and not as replacements for real laboratories where such laboratories are available. Nonetheless, when a real laboratory is unavailable or inaccessible, such materials can of course be very useful indeed. We believe that their ideal use is as a teaching resource that can be used for pre-practical and post-practical study, allowing the acquisition of knowledge to be more efficient. But again, in sum we conclude that, to enhance our students' learning it is important to integrate these materials as complementary methods added to those used in traditional teaching.

With respect to the computer simulations that were developed and implemented in this work, we have demonstrated with our students that this type of computer simulation which we call "hyper-realistic" represents reality with a realism far above that of the usual simulations (Pérez et al., 2011). Specifically, we validated the educational effectiveness of the hyper-realistic virtual environment that we implemented with an experimental design that included a control group of students and an experimental group. The results of the different evaluation tests showed that our simulations resolve some of the weaknesses of the usual computer simulations, such as those deriving from their simplicity and lack of realism of the graphical environment viewed by the student. These simulations offer the student the opportunity to perform Optics practicals at any time. This obviates the problem typical of eminently practical subjects in that the individual work required of the student is usually 
limited to mere theoretical studies, since the student lacks the appropriate material for additional practice outside the laboratory. Appropriately designed hyper-realistic computer simulations are highly effective teaching tools in certain educational contexts, for example, on e-learning platforms.

The work and the materials that it generated have been and are being used both by our Engineering and Physical Sciences undergraduate students and by our students of various official Master Degree courses that we teach on Physics Education. In addition, teachers of several Latin American universities have told us they are also using them with their students.

We believe that the teaching material we have developed and the form of using it are transferable to other subjects and innovation projects at the university level, which would facilitate future proposals for the use of our materials in other subjects different from those dealt with in this work. Now we have started working on the generation of the videos and simulations described in this work using Stereoscopic-3D technology. To generate photorealistic three-dimensional simulations we are using technology based on ray tracing combined with 3D display technology.

\section{Acknowledgment}

This research has been partially funded by the European Regional Development Fund through the Regional Government of Extremadura, grant GR10102.

\section{References}

Adell, J. (1997). Tendencias en educación en la sociedad de las tecnologías de la información. Edutec. Revista Electrónica de Tecnología Educativa, Vol. 7, ISSN 1135-9252

Adell, J. (2005). Internet en educación. Comunicación y Pedagogía, Vol. 200, pp. 25-28, ISSN $1136-7733$

Aktan B., Bohus, C., Crowl, A., \& Shor, M. H. (1996). Distance learning applied to control Engineering Laboratories. IEEE Transactions on Education, Vol. 39, No. 3, pp. 320326, ISSN 0018-9359

Aleksandrov, A., \& Nancheva, N. (2007). Systems of Teaching Engineering Work on Base of Internet Technologies. International Journal of Information Technologies and Knowledge, Vol. 1, pp. 37-44, ISSN 1313-0455

Alessi, S. M., \& Trollip, S. R. (Eds.) (1991). Computer-based instruction: Methods and development (2nd ed.), Prentice Hall, ISBN 978-0131685925, Englewood Cliffs, NJ

Alpert, S. R., \& Grueneberg, K. (2001). Concept mapping with multimedia on the Web. Journal of Educational Multimedia and Hypermedia, Vol. 9, No. 4, pp. 313-330, ISSN 1055-8896

Anderson-Inman, L., \& Ditson, L. (1999). Computer-based concept mapping: A tool for negotiating meaning. Learning and Leading with Technology, Vol. 26, No. 8, pp. 6-13, ISSN 1082-5754

Area, M. (2005). Tecnologías de la información y la comunicación en el sistema escolar. Una revisión de las líneas de investigación. Revista Electrónica de Investigación y Evaluación Educativa, Vol. 11, No. 1, pp. 3-25, ISSN 1134-4032 
Arvaja, M., Salovaara, H., Häkkinen, P., \& Järvelä, S. (2007). Combining individual and group-level perspectives for studying collaborative Knowledge construction in context. Learning and Instruction, Vol. 17, No. 4, pp. 448-459, ISSN 0959-4752

Ausubel, D. P. (1968). Educational psychology: A cognitive view, Holt McDougal, ISBN 9780030899515, New York

Ausubel, D.P. (2000). The acquisition and retention of knowledge: a cognitive view, Springer, ISBN 978-0792365051, Dordrecht

Baily, C., \& Finkelstein, N.D. (2009). Development of quantum perspectives in modern physics, Physical Review Special Topics - Physics Education Research, Vol. 5, pp. 010106, ISSN 1554-9178

Bajarlía, G., \& Speigel, A. (1997). Docentes us@ndo Internet, Ediciones Novedades Educativas, ISBN 978-9879191161, Buenos Aires

Balanskat, A., Blamire, R., \& Kefala, S. (2007). Insight: Observatory for new technologies and education. Retrieved on August 1, 2011, Available from http://insight.eun.org/ww/en/pub/insight/misc/specialreports/impact_study.htm

Barberá, E., Mauri, T., \& Onrubia, J. (Eds.) (2008). Cómo valorar la calidad de la enseñanza basada en las TIC: Pautas e instrumentos de Análisis, Graó, ISBN 978-8478275304, Barcelona

Bartolomé, A. (1996). Preparando para un nuevo modo de conocer, Edutec. Revista Electrónica de Tecnología Educativa, Vol. 4, ISSN 1135-9252

Beichner, R., Bernold, L., Burniston, E., Dail, P., Felder, R., Gastineau, J., Gjersten, M., \& Risley, J. (1999). Case study of the physics component of an integrated curriculum. American Journal of Physics, Vol. 67, No. 7, pp. 16-24, ISSN 0002-9505

Beller, M. O. (1998). The crossroads between lifelong learning nd information technology. A challenge facing leading universities. Journal of Computer-Mediated Communication, Vol. 4, No. 2, pp. 9-19, ISSN 1083-6101

Blease, D., \& Cohen, L. (1990). Coping with computers: an ethnographic study in primary classrooms, Paul Chapman Educational Publishing, ISBN 978-1853960659, London.

Bryan, J.A., \& Slough, S.W. (2009). Converging lens simulation design and image predictions. Physics Education, Vol. 44, No. 3, pp. 264-275, ISSN 0031-9120

Cabero, J., Castaño, C., Cebreiro, B., Gisbert, M., Martinez, F., Morales, J.A., Prendes, M.P., Romero, R., \& Salinas, J. (2003). Las nuevas tecnologías en la actividad universitaria, Pixel Bit. Revista de Medios y Educación, Vol. 20, pp. 81-100, ISSN 11338482

Calvo, J.L. \& Pérez, A.L. (1983). Teaching oscillations with a small computer. Physics Education, Vol. 18, No. 4, pp. 172-174, ISSN 0031-9120

Calvo, I., Marcos, M., Orive D., \& Sarachaga I. (2009). Building Complex Remote Laboratories. Computer Applications in Engineering Educations, Vol. 18, No. 1, pp. 5366, ISSN 1099-0542

Candelas, F.A., Gil, P., Torres, F., Ortiz, F., Puente, S.T., \& Pomares, J. (2004). Virtual remote laboratory for teaching of computer vision and robotic in the University of Alicante. Proceedings of the IBCE'04, Second IFAC Workshop on Internet Based Control Education, Grenoble (France), September 2004

Cañas, A. J., Ford, K. M., Coffey, J., Reichherzer, T., Carff, R., Shamma, D., \& Breedy, M. (2000). Herramientas para Construir y Compartir Modelos de Conocimiento basados en Mapas Conceptuales. Revista de Informática Educativa, Vol. 13, N. 2, pp. 145-158 
Cattagni, A., \& Farris, E. (2001). Internet Access in US. Public Schools and Classrooms: (1994-2000). USA: National Center for Education Statistics. Retrieved on August 1, 2011, Available from http://nces.ed.gov/pubs2001/2001071.pdf

Cebrián, M., Ruiz, J., \& Rodríguez, J. (2007). Estudio del impacto del Proyecto TIC desde la opinión de los docentes y estudiantes en los primeros años de su implantación en los centros públicos de Andalucía. Universidad de Málaga, Grupo de Investigación en Nuevas Tecnologías aplicadas a la Educación.

Cebrián, M. (1997) Nuevas competencias para la formación inicial y permanente del profesorado. Edutec. Revista Electrónica de Tecnología Educativa, Nº 6, ISSN 1135-9252

Chang, K.E-, Yu-Lung, C., Lin, H-Y., \& Sung, Y.T. (2008). Effects of learning support in simulation-based physics learning. Computers $\mathcal{E}$ Education, Vol. 51, No. 4, pp. 14861498, ISSN 0360-1315

Chi, M.T.H., Siler, S., Jeong, H., Amauchi, T., \& Hausmann, R.G. (2001). Learning from human tutoring. Cognitive Science, Vol. 25, No. 4, pp. 471-533, ISSN 0364-0213

Cifuentes, L., \& Hsieh, Y.C. (2003). Visualization for construction of meaning during study time: A quantitative analysis. International Journal of Instructional Media, Vol. 30, No. 3, pp. 263-273, ISSN 0092-1815

Cline, B.E., Brewster, C.C., \& Fell, R.D. (2010). A rule-based system for automatically evaluating student concept maps. Source Expert Systems with Applications, Vol. 37, No. 3, pp. 2282-2291, ISSN 0957-4174

Coll, C. (2004). Psicología de la educación y prácticas educativas mediadas por las tecnologías de la información y la comunicación. Una mirada constructivista. Sinéctica, Vol. 25, pp. 1-24 (offprint), ISSN 1665-109X

Coll, C., Mauri, T., \& Onrubia, J. (2008). Análisis de los usos reales de las TIC en contextos educativos formales: una aproximación sociocultural. Revista Electrónica de Investigación Educativa, Vol. 10, No. 1, ISSN 1607-4041

Coll, C., Onrubia, J., \& Mauri, T. (2007). Tecnología y prácticas pedagógicas: Las TIC como instrumentos de mediación de la actividad conjunta de profesores y estudiantes. Anuario de Psicología, Vol. 38, No. 3, pp. 377-400, ISSN 0066-5126

Crook, C. (1996). Computers and the Collaborative Experience of Learning, Routledge, ISBN 9780415053600, London

Cuban, L. (2001). Oversold $\mathcal{E}$ Underused. Computers in the Classroom, Harvard University Press, ISBN 978-0674011090, Cambridge, MA

Dede, C. (Ed.) (1998) Learning with Technology (1998 ASCD Yearbook), Association for Supervision \& Curriculum Deve, ISBN 978-0871202987, Las Vegas

Difanzo, N., Hantula, D. A., \& Bordia, P. (1998). Microworlds for experimental research, Having your (control and collection) cake, and realism too. Behavioural Research Methods, Instruments, and Computers, Vol. 30, No. 2, pp. 278-286, ISSN 0743-3808

Dockstader, J. (1999) Teachers of the 21st Century know the what, why, and how of technology integration. Technological Horizons in Education Journal, Vol. 26, No. 6, pp. 73-74, ISSN 0192-592X

Domínguez M., Reguera, P. \& Fuertes, J.J. (2005). Laboratorio Remoto para la Enseñanza de la Automática en la Universidad de León (España). Revista Iberoamericana de Automática e Informática Industrial, Vol. 2, No. 2, pp. 36-45, ISSN 1697-7912

Donnelly, R. (2005). Using technology to support project and problem-based learning, In: Handbook of Enquiry \& Problem Based Learning, Barreto, T., Maclabhrainn, I., \& Fallon, H. (Eds.), pp. 157-177, CELT, ISBN 978-095516980, Galway 
Dormido, S. (2004). Control Learning: Present and Future. Annual Reviews in Control, Vol. 28, No. 1, pp. 115-136, ISSN 1367-5788

Eylon, B. S., Ronen, M., \& Ganiel, U. (1996). Computer simulations as tools for teaching and learning: using a simulation environment in optics. Journal of Science Education and Technology, Vol. 5, No. 2, pp. 93-110, ISSN: 1059-0145

Finkelstein, N.D., Adams, W. K., Keller, C. J., Kohl, P. B., Perkins, K. K., Podolefsky, N. S., \& Reid, S. (2005). When Learning about the Real World is Better Done Virtually. Physic review Special Topics - Physics Education Research Vol. 1, pp. 010103, ISSN 1554-9178

Finol de Govea, A. (2007). Principios Cognitivo-constructivistas en la Aplicación de las Tecnologías de la Información y la Comunicación (TIC) para la EnseñanzaAprendizaje de Inglés con Propósitos Específicos. SYNERGIES, Vol. 3, pp. 38-64, ISSN 1856-035X

García, A., \& Gil, M. (2006). Entornos Constructivistas de Aprendizaje Basados en Simulaciones Informática. Revista Electrónica de Enseñanza de las Ciencias, Vol. 5, No. 2, pp. 304-322, ISSN 1579-1513

Garrison, D.R., \& Anderson, T. (2003). E-learning in the 21st century: a framework for research and practice, Routledge, ISBN 978-0415263467, London

Goldberg, F., \& Bendall, S. (1995). Making the invisible visible: A teaching/learning environment that builds on a new view of the physics learner. American Journal of Physics, Vol. 63, No. 11, pp. 978-991, ISSN 0002-9505

Goldberg, F. (1997). Constructing physics understanding in a computer-supported learning environment. AIP Conference Proceedings Vol. 399, pp. 903-911.

Goldstone, R., \& Sakamoto, Y. (2003). The transfer of abstract principles governing complex adaptive systems. Cognitive Psychology, Vol. 46, No. 4, pp. 414-466, ISSN 0010-0285

Goldstone, R., \& Son, J.Y. (2005). The Transfer of Scientific Principles Using Concrete and Idealized Simulations. The Journal of the Learning Sciences, Vol. 14, No. 1, pp. 69-110, ISSN 1050-8406

Goodyear, P., Njoo, M., Hijne, H., \& Van Berkum, J.J.A. (1991). Learning processes, learner attributes and simulations. Education E Computing, Vol. 6, No. 3, pp. 263-304, ISSN 0167-9287

Gorsky, P., \& Finegold, M. (1992). Using computer simulations to restructure student's conceptions of force. Journal of Computers in Mathematics and Science Teaching, Vol. 11, No. 2, pp. 163-178, ISSN 0731-9258

Grabe, M., \& Grabe, C. (1996). Integrating technology for meaningful learning, Wadsworth Publishing, ISBN 978-0618637010, Boston

Grady, S.M. (1998). Virtual reality: Computers mimic the physical world, Facts on File, ISBN 9780816036059, New York

Gross, B. (2000). El ordenador invisible, hacia la apropiación del ordenador en la enseñanza, Editorial Gedisa, ISBN 978-8474327595, Barcelona

Guzmán J. L., Rodríguez, F., Berenguel, M., \& Dormido, S. (2005). Laboratorio virtual para la enseñanza de control climático de invernaderos Revista iberoamericana de automática e informática industrial, Vol. 2, No. 2, pp. 82-92, ISSN 1697-7912

Harper, B., Squires, D., \& Mcdougall, A. (2000). Constructivist Simulations: A New Design Paradigm. Journal of Educational Multimedia and Hypermedia, Vol. 9, No.2, pp. 115130, ISSN 1055-8896 
Harris, M.H. (1999). Is the revolution now over, or has it just begun? A year of the Internet in Higher Education. The Internet \& Higher Education, Vol. 1, No.4, pp. 243-251, ISSN 1096-7516

Haugwitz, M., Nesbit, J.C., \& Sandmann, A. (2010). Cognitive ability and the instructional efficacy of collaborative concept mapping. Learning and Individual Differences, Vol. 20, No. 5, pp. 536-543, ISSN 1041-6080

Hewson, P.W. (1985). Diagnosis and remediation of an alternate conception of velocity using a microcomputer program, American Journal of Physics, Vol. 53, No. 7, pp. 684-690, ISSN 0002-9505

Järvelä, S., \& Häkkinen, P. (2002). Web-based cases in teaching and learning-the quality of discussions and a stage of perspective taking in asynchronous communication. Interactive Learning Environments, Vol. 10, No. 1, pp. 1-22, ISSN 1049-4820

Jonassen, D.H. (1996). Computers in the classroom: Mindtools for critical thinking, Prentice Hall, ISBN 978-0023611919, Columbus, $\mathrm{OH}$

Jonassen, D.H. (2000). Computer as mindtools for schools: Engaging critical thinking, Prentice Hall, ISBN 978-0130807090, Upper Saddle River, NJ

Kaput, J.J. (1995) Creating cyberetic and psychological ramps from the concrete to the abstract: Examples from multiplicate structure, In: Software goes to schools: Teaching for understanding with new technologies, D. N. Perkins, J. L. Schwartz, M. M. West, \& M. S. Wiske (Eds.), pp. 130-154, Oxford University Press, ISBN 978-0195115772, New York

Kennewell, S., \& Beauchamp, G. (2003). The influence of a technology-rich classroom environment on elementary teachers' pedagogy and children's learning. Proceedings of the IFIP Working Group 3.5. Conference: Young Children and Learning Technologies, University of Wales Swansea, Parramata (UK), July 2003

Kwon, S.Y., \& Cifuentes, L. (2009). The comparative effect of individually-constructed vs. Collaboratively-constructed computer-based concept maps. Computers $\mathcal{E}$ Education Vol. 52, No. 2, pp. 365-375, ISSN 0360-1315

Lajoie, S.P., Azevedo, R., \& Fleiszer, D. (1998). Cognitive tools for assessment and learning in high information flow environment. Journal of Educational Computing Research, Vol. 18, No. 3, pp. 205-235, ISSN 0735-6331

Lajoie, S.P. (2000). Computers as Cognitive Tools, Vol. II: No More Walls, Routledge, ISBN 9780805829310, London

Lajoie, S.P., \& Azevedo, R. (2006). Teaching and learning in technology-rich environments, In: Handbook of Educational Psychology. (2nd ed.), Alexander, P., \& Wine, P. (Eds.), pp. 803-821, Lawrence Erlbaum Associates, ISBN 978-0805859713, Mahwah, NJ

Landau, R. (2006). Computational Physics: A Better Model for Physics Education? Computing in Science \& Engineering, Vol. 8, No. 5, pp. 22-30, ISSN 1521-9615

Laschi, R., \& Riccioni, A. (2008). Design and Implementation of a Virtual Lab for Supporting Students in Modeling, Evaluating and Programming Secure Systems, Proceedings of the 12th International Conference on Interactive Computer-Aided Learning (ICL 2008), Villach (Austria), September 2008

Lehtinen, E., Hakkarainen, K., Lipponen, L., Rahikainen, M., \& Muukkonen, H. (1999). Computer supported collaborative learning: A review of research and development. The J.H.G.I. Giesbers Reports on Education, 10. Retrieved on August 1, 2011, Available from http://www.comlab.hut.fi/opetus/205/etatehtava1.pdf 
Linn, M.C. (2002). Promover la educación científica a través de las tecnologías de la información y comunicación (TIC). Enseñanza de las Ciencias. Vol. 20, No. 3, pp. 347355, ISSN 0212-4521

López, M., \& Morcillo, J.G. (2007). Las TIC en la enseñanza de la Biología en la educación secundaria: los laboratorios virtuales. Revista Electrónica de Enseñanza de las Ciencias, Vol. 6, No. 3, pp. 562-576, ISSN 1579-1513

Marqués, P. (2000). Impacto de las TIC en educación: funciones y limitaciones. Enciclopedia Virtual de Tecnología Educativa. Vol. 194, pp. 48-51, ISSN 1133-9926

Martínez, G., Pérez, A. L., Suero, M. I., \& Pardo, P. J. (2010a). Comparación del incremento de aprendizaje obtenido al utilizar mapas conceptuales y Cmaptools en el estudio de dos temas diferentes, pero de nivel de contenido conceptual equivalente. Proceedings of the Fourth International Conference on Concept Mapping, ISBN 9789561907058, Viña del Mar (Chile), October 2010

Martínez, G., Pérez, A. L., Suero M. I., Naranjo. F. L., \& Pardo, P. J. (2010b). Implementación de un laboratorio virtual de placas solares fotovoltaicas para el desarrollo de prácticas no presenciales. Proceedings of ticEDUCA2010: Encontro International TIC e Educaçao, ISBN 978-9899699915, Lisboa (Portugal), November 2010

Martínez, G., Pérez, A. L., Suero M. I., Naranjo. F. L., \& Pardo, P. J. (2011). Diseño, elaboración y validación de Videos Didácticos sobre Prácticas de Comunicaciones Ópticas. Proceedings of the XIX Encuentro Ibérico para la Enseñanza de la Física y XXXIII Reunión Bienal de la RSEF, Santander (Spain)

Mauri, T., Onrubia, J., Coll, C., \& Colomina, R. (2005). La calidad de los contenidos educativos reutilizables: diseño, usabilidad y prácticas de uso. RED-Revista de Educación a Distancia, Vol. 2, ISSN 1578-7680

Mauri, T. (2006). Análisis de casos con TIC en la formación inicial del conocimiento profesional experto del profesorado. Revista Interuniversitaria de Formación de Profesorado, Vol. 20, No. 3, pp. 219-231, ISSN 1575-0965

Merrill, P., Hammons, K., \& Vincent, B. (1996). Computers in Education (3rd Edition), Allyn \& Bacon, ISBN 978-0205185177, Boston

Moreira, M.A. (2010). ¿Por qué conceptos? ¿Por qué aprendizaje significativo? ¿Por qué actividades colaborativas? ¿Por qué mapas conceptuales? Revista Qurriculum, Vol. 23, pp. 9-23, ISSN 1130-5371

Naps, T. L., Rößling, G., Almstrum, V., \& Dann, W. (2003). Exploring the Role of Visualization and Engagement in Computer Science Education. ACM SIGCSE Bulletin, Vol. 35, No. 2, pp. 131-152, ISSN 0097-8418

Novak, J.D., \& Gowin, D.B. (1984). Learning how to learn, Cambridge University Press, ISBN 978-0521319263, London

Novak, J.D., \& Musonda, D. (1991). A twelve-year longitudinal study of science concept learning. American Educational Research Journal, Vol. 28, No. 1, pp. 117-153, ISSN 0002-8312

Novak, J.D., \& Cañas, A.J. (2006). The Theory Underlying Concept Maps and How to Construct Them, Technical Report IHMC CmapTools 2006-01, Florida Institute for Human and Machine Cognition, retrieved on August 1, 2011, Available from: http://cmap.ihmc.us/Publications/ResearchPapers/TheoryUnderlyingConceptMaps.pdf

Okebukola, P.A., \& Jegede, O.J. (1988). Cognitive preference and learning mode as determinants of meaningful learning through concept mapping. Science Education, Vol. 72, No. 4, pp. 489-500, ISSN 0036-8326 
Onrubia, J. (2005). Aprender en entornos virtuales de enseñanza y aprendizaje: actividad conjunta, ayuda pedagógica y construcción del conocimiento" RED-Revista de Educación a Distancia, Vol. 2, ISSN 1578-7680

Pérez, A.L.; Peña, J.J.; Mahedero, B. (1979a). Electronic Device of Didactic and Electrometric Interest for the Study of RLC Circuits. American Journal of Physics. Vol. 47, No. 2, pp. 178-181, ISSN 0021-8979

Pérez, A.L.; Peña, J.J.; Bueno, M.A.; Vega J.M., \& Calvo. J.L. (1979b) Reinforcing the study of impedance. Physics Education, Vol. 14, No. 5, pp. 250-252, ISSN 0031-9120

Pérez, A.L. and Calvo, J.L. (1984). A small electronic device for studing chemical kinetics. Journal of chemical educations, Vol. 61, No.9, pp. 808-810, ISSN 0021-9584

Pérez, A. L.; Suero, M. I.; Montanero, M., \& Montanero, F. M. (1999). Mapas de experto tridimensionales. Aplicaciones al diseño de secuencias instruccionales de física, basadas en la teoría de elaboración, In: Premios nacionales de investigación educativa, pp. 93-116, CIDE, ISBN 978-8436932870, Madrid

Pérez, A.L., Suero, M.I., Montanero, F.M., Montanero, M., \& Pardo, P.J. (2000): Threedimensional conceptual maps: an illustration for the logical structure of the content of optic, Proceedings of the International Conference Physics Teacher Education. Beyond 2000, ISBN 978- 8469944169, Barcelona (Spain), August 2000

Pérez, A.L., Suero, M.I., Pardo, P.J., \& Montanero, M. (2004). Aplicaciones de la teoría de Reigeluth y Stein a la Enseñanza de la Física. Una propuesta basada en la utilización del programa informático Cmaptools. Proceedings of the First Internacional Conference on Concept Mapping, ISBN 978-8497690648, Pamplona (Spain), September 2004

Pérez, A.L., Suero, M.I., Pardo, P.J., \& Montanero, M. (2006). Utilización de Cmaptools en la reconstrucción colaborativa de conocimientos sobre la reflexión de la luz. Proceedings of the Second Internacional Conference on Concept Mapping, ISBN 978-9977151482, San José (Costa Rica), September 2006

Pérez A.L., Suero, M.I., \& Pardo, P.J. (2008). Utilización de Cmaps para mejorar los conocimientos relativos a la refracción de la Luz mediante su "Reconstrucción Colaborativa". Óptica pura y aplicada, Vol. 41, No. 1, pp. 17-23, ISSN 0030-3917

Pérez, A.L., Suero, M.I., Montanero, M., Pardo, P.J., \& Montanero, M. (2010a). Concept maps and conceptual change in physics, In: Handbook of research on Collaborative learning using concept mapping, Lupion Torres, P., Cássia Veiga Marriott, R. (Eds.), pp. 325345, Idea Group Publishing, ISBN 978-1599049939, Hershey

Pérez, A.L., Martínez, G., Suero, M.I., \& Pardo, P.J. (2010b). Determinación experimental del incremento de aprendizaje obtenido mediante la utilización de mapas conceptuales y Cmaptools. Comparación de la cantidad de aprendizaje sobre las fibras ópticas conseguido utilizando mapas conceptuales y sin utilizarlos. Proceedings of the Fourth International Conference on Concept Mapping, ISBN 978-9561907058, Viña del Mar (Chile), October 2010

Pérez, A.L., Martínez, G., Suero, M.I., Naranjo, F.L., \& Pardo, P.J. (2011). Estudio comparativo de la eficacia de varios entornos de aprendizaje: simulaciones virtuales hiperrealistas, simulaciones esquemáticas y laboratorio tradicional. Proceedings of the XIX Encuentro Ibérico para la Enseñanza de la Física y XXXIII Reunión Bienal de la RSEF, Santander (Spain) 
Poves, J. (1997). Docencia y aprendizaje en la red: La red de estudiantes de la UAM, Proceedings of the II Congreso Nacional de Usuarios de Internet e Infovía, Madrid (Spain), February 1997

Pov-Ray. Persistence Of Vision Raytracer. Retrieved on august 1, 2011, Available from http://www.povray.org/

Psillos, D., \& Niedderer, H. (2002). Teaching and learning in the science laboratory, Kluwer Academic Publishers, ISBN 978-1402010187, Dordrecht

Reader, W., \& Hammond, N. (1994). Computer-based tools to support learning from hypertext: Concept mapping tools and beyond. Computers $\mathcal{E}$ Education, Vol. 12, No. 1-2, pp. 99-106, ISSN 0360-1315

Reigeluth, C. M. (Ed.) (1983). Instructional design theories and models: an overwiev of their current status, Routledge, ISBN 978-0898592757, London

Reparaz, C.H., Sobrino, A., \& Mir, J. (2000). Integración curricular de las nuevas tecnologías. Editorial Ariel S.A., ISBN 978-8434428713, Barcelona.

Riccioni, A. (2010). Design, Implementation and Evaluation of a Virtual Laboratory for Computer Engineering Education. Thesis, (PhD), Università Degli Studi Di Bologna.

Roca, O. (2001) La autoformación y la formación a distancia: la tecnología de la educación en los procesos de aprendizaje, In: Para una tecnología educativa, Sancho, J. (Ed.), pp. 169-192, Horsori Editorial, ISBN 978-8485840311, Barcelona.

Ronen, M., \& Eliahu, M. (2000). Simulation - a bridge between theory and reality: the case of electric circuits. Journal of computer assisted learning, Vol. 16, No. 1, pp. 14-26, ISSN 0266-4909

Roth, W.M., \& Roychoudhury, A. (1994). Science discourse through collaborative concept mapping: new perspectives for the teacher. International Journal of Science Education, Vol. 16, No. 4, pp. 437-455, ISSN 0950-0693

Salomon, G., Perkins, D.N., \& Globerson, T. (1991). Partners in cognition: Extending human intelligence with intelligent technologies. Educational Researcher, Vol. 20, No. 3, pp. 2-9, ISSN 0013-189X

Salzmann, Ch., Gillet, D., \& Huguenin, P. (2000). Introduction to Real Time Control using labview with an Application to Distance Learning. International Journal of Engineering Education, Vol. 16, No. 3, pp. 255-272, ISSN 0949-149X

Sánchez, J. (2000). Nuevas tecnologías de la información y comunicación para la construcción del aprender, Universidad de Chile, ISBN 978-9562888436, Santiago de Chile.

Sánchez, J. (2001). Aprendizaje visible, tecnología invisible, Dolmen Ediciones ISBN 9789562014738, Santiago de Chile

Shin, N., Jonassen, D. H., \& McGee S. (2003). Journal of Research in Science Teaching, Vol. 40, No. 1, pp. 6-33, ISSN 0022-4308.

Sims, R. (2000). An interactive conundrum: Constructs of interactivity and learning theory. Australian Journal of Educational Technology, Vol. 16, No.1, pp. 45-5, ISSN 0814-673X

Snir, J., Smith, C., \& Grosslight, L. (1995). Conceptually enhanced simulations: A computer tool for science teaching, In: Software goes to school: Teaching for understanding with new technologies, D. N. Perkins, J. L. Schwartz, M. M. West, \& M. S. Wiske (Eds.), pp. 106-129, Oxford University Press, ISBN 978-0195115772, New York

Squires, D., \& McDougall, S. (1994). Choosing and using educational software: a teacher's guide. Falmer Press, ISBN 978-0750703062, London

Steinberg, R.N. (2000). Computers in teaching science: To simulate or not to simulate? American Journal of Physics, Vol. 68, No. 1, pp. 37-41, ISSN 0002-9505 
Suero, M.I., Pérez, A.L., Martínez, G. and Pardo, P.J. (2010). Determinación experimental del incremento de aprendizaje obtenido mediante la utilización de mapas conceptuales y Cmaptools. Comparación de la cantidad de aprendizaje obtenido por los alumnos utilizando mapas conceptuales y sin utilizarlos. Proceedings of the Fourth International Conference on Concept Mapping, ISBN 978-9561907058, Viña del Mar (Chile), October 2010

Tao, P., \& Gunstone, R. (1999). The process of conceptual change in force and motion during computer-supported physics instruction. Journal of Research in Science Teaching, Vol. 36, No. 7, pp. 859-882, ISSN 0022-4308

Tao, P. (2004). Developing understanding of image formation by lenses through collaborative learning mediated by multimedia computer-assisted learning programs. International Journal of Science Education, Vol. 26, No. 10, pp. 1171-119, ISSN 0950-0693

Tascón, C. (2002). Principios Psicoinstruccionales de la Formación en la sociedad de la información y la comunicación. Proceedings of the I Congreso Internacional Sociedad de la Información, ISBN 978-8448136039, Las Palmas de Gran Canaria (Spain), February 2002

Tondeur, J., Van Braak, J., \& Valcke, M. (2007). Towards a typology of computer use in primary education. Journal of Computer Assisted Learning, Vol. 23, No. 3, pp. 197-206, ISSN 0266-4909

Trumper, R. (2003). The physics laboratory - an historical overview and future perspectives. Science E Education, Vol. 12, pp. 645-670, ISSN 0926-7220

Twining, P. (2002). Conceptualising computer use in education: Introducing the Computer Practice Framework (CPF). British Educational Research Journal, Vol. 28, No. 1, pp. 95-110, ISSN 0141-1926

UNESCO (2000). Report of the Expert Meeting on Virtual Laboratories. UNESCO, Paris. Retrieved on August 1, 2011, Available from: http:/ / unesdoc.unesco.org/images/0011/001191/119102eo.pdf

Vélez, G. (2002). Aprender en la Universidad. La relación del estudiante universitario con el conocimiento. Universidad Nacional de Río Cuarto, ISBN 978-9506652031, Córdoba

Yanitelli, M.S. (2011). Un cambio significativo en la Enseñanza de las Ciencias. El uso del ordenador en la resolución de situaciones experimentales de Física en el nivel universitario básico. Thesis (PhD), Universidad de Burgos.

Yazon, J.M.O., Mayer-Smith, J.A., \& Redfield, R.J. (2002). The impact of a web-based genetics course on university students' perspectives on learning a teaching. Computers $\mathcal{E}$ Education, Vol. 38, No. 1-3, pp. 267-285, ISSN 0360-1315

Zacharia, Z., \& Anderson, O. R. (2003). The effects of an interactive computer-based simulation prior to performing a laboratory inquiry-based experiment on students' conceptual understanding of physics. American Journal of Physics, Vol. 71, No. 6, pp618-629, ISSN 0002-9505

Zhao, Y., Pugh, K., Sheldon, S. \& Byers, J. L. (2002). Conditions for classroom technology innovations. Teachers College Record, Vol. 104, No. 3, pp. 482-515, ISSN 0161-4681

Zhao, Y. \& Frank, K. A. (2003). Factors affecting technology uses in schools: an ecological perspective. American Educational Research Journal, Vol. 40, No. 4, pp. 807-840, ISSN 0002-8312 


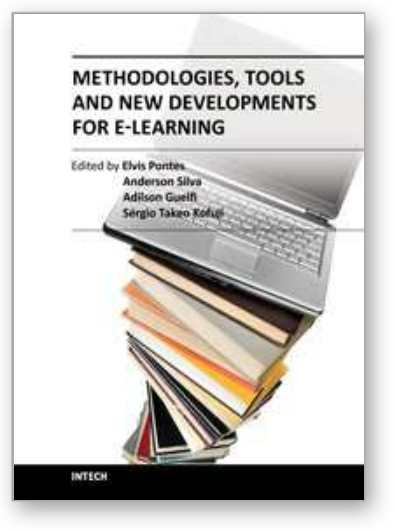

\author{
Methodologies, Tools and New Developments for E-Learning \\ Edited by Dr. Elvis Pontes
}

ISBN 978-953-51-0029-4

Hard cover, 332 pages

Publisher InTech

Published online 03, February, 2012

Published in print edition February, 2012

With the resources provided by communication technologies, E-learning has been employed in multiple universities, as well as in wide range of training centers and schools. This book presents a structured collection of chapters, dealing with the subject and stressing the importance of E-learning. It shows the evolution of Elearning, with discussion about tools, methodologies, improvements and new possibilities for long-distance learning. The book is divided into three sections and their respective chapters refer to three macro areas. The first section of the book covers methodologies and tools applied for E-learning, considering collaborative methodologies and specific environments. The second section is about E-learning assessment, highlighting studies about E-learning features and evaluations for different methodologies. The last section deals with the new developments in E-learning, emphasizing subjects like knowledge building in virtual environments, new proposals for architectures in tutoring systems, and case studies.

\title{
How to reference
}

In order to correctly reference this scholarly work, feel free to copy and paste the following:

Guadalupe Martínez, Ángel Luis Pérez, $M^{a}$ Isabel Suero and Pedro J. Pardo (2012). ICTs and Their Applications in Education, Methodologies, Tools and New Developments for E-Learning, Dr. Elvis Pontes (Ed.), ISBN: 978-953-51-0029-4, InTech, Available from: http://www.intechopen.com/books/methodologies-toolsand-new-developments-for-e-learning/icts-and-their-applications-in-education

\section{INTECH}

open science | open minds

\author{
InTech Europe \\ University Campus STeP Ri \\ Slavka Krautzeka 83/A \\ 51000 Rijeka, Croatia \\ Phone: +385 (51) 770447 \\ Fax: +385 (51) 686166 \\ www.intechopen.com
}

\author{
InTech China \\ Unit 405, Office Block, Hotel Equatorial Shanghai \\ No.65, Yan An Road (West), Shanghai, 200040, China \\ 中国上海市延安西路65号上海国际贵都大饭店办公楼 405 单元 \\ Phone: +86-21-62489820 \\ Fax: +86-21-62489821
}


(C) 2012 The Author(s). Licensee IntechOpen. This is an open access article distributed under the terms of the Creative Commons Attribution 3.0 License, which permits unrestricted use, distribution, and reproduction in any medium, provided the original work is properly cited. 